\title{
Physical activity level and leisure time satisfaction in higher vocational school students
}

\section{Önlisans öğrencillerinde fiziksel aktivite düzeyi ve serbest zaman memnuniyeti}

\author{
Aysun Yağci Şentüirk, Elif Okur
}

\section{Trabzon University Tonya Higher Vocational School, Tonya, Trabzon, Turkey}

Corresponding author: Aysun Yağci Şentürk, Trabzon University Tonya Higher Vocational School, Tonya, Trabzon, Turkey

E-mail: aysunsenturk@trabzon.edu.tr

Received/Accepted: June 01, 2020 / July 06, 2020

Conflict of interest: There is not a conflict of interest.

\section{SUMMARY}

Objective: Today, increasing desk bound activities cause sedentary lifestyle in young adults. Therefore, in the planned study, the relationship between physical activity level and leisure time satisfaction was examined and it was aimed to determine the factors affecting physical activity and leisure time satisfaction.

Method: A cross-sectional study was conducted on 130 associate degree students. Demographic data form and International Physical Activity Qustionnaire(IPAQ) short form and Leisure Time Satisfaction Scale(LTSS) long form were used in the study. Results were evaluated at $95 \%$ confidence interval and $\mathrm{p}<0.05$ significance level.

Results: $79.2 \%$ of the students were female students. It was revealed that $11.54 \%$ of the students had low, $45.38 \%$ had moderate and $43.08 \%$ had high physical activity levels. There was no significant relationship between body mass index and physical activity. Height, body weight and gender were determined as factors affecting physical activity level. Physical activity levels were significantly higher in male students $(\mathrm{p}<0.05)$. According to the LTSS, the mean score of the students was $87.97 \pm 8.91$. Leisure time satisfaction rate was higher in obese students. There was a negative correlation between students' LTSS and IPAQ total scores $(r=-0.180$, $\mathrm{p}<0.05)$.

Conclusions: According to the results of the study, physical activity levels and leisure time satisfaction of higher vocational school students were not high enough. In line with the recommendations of the World Health Organization, taking steps to increase physical activity and active leisure time activities in young adults is important for a healthy life.

Keywords: Exercise, healthy lifestyle, leisure activities, recreation, sports, students

Ethical Approval: Karadeniz Technical University Medical Faculty Scientific Research Ethics Committee (approval number 24237859-859)

Informed Consent: Written informed consent form was obtained.

Acknowledgements: We thank to students who participated in this study and the translator for her help.
Aysun Yağci Şentürk

Elif Okur

ORCID IDs of the authors:

A.Y.Ş. 0000-0002-4802-3063

E.O. 0000-0003-2608-8584 
Amaç: Günümüzde masa başı faaliyetlerin artması genç yetişkinlerde hareketsiz yaşam tarzına neden olmaktadır. Bu nedenle planlanan çalı̧̧mada fiziksel aktivite düzeyi ile serbest zaman memnuniyeti arasındaki ilişki incelenmiş ve fiziksel aktivite ile serbest zaman memnuniyeti üzerinde etkili olan faktörlerin belirlenmesi amaçlanmıştır.

Yöntem: Kesitsel tipte yapılan araştırma 130 önlisans öğrencisi üzerinde gerçekleştirildi. Araştırma kapsamında verilerin elde edilmesinde sosyodemografik veri formu ve Uluslararası Fiziksel Aktivite Ölçeği kısa formu ile Serbest Zaman Tatmin Ölçeği uzun formu kullanıldı. Sonuçlar \%95 güven aralığında ve $p<0,05$ anlamlılık düzeyinde değerlendirildi.

Bulgular: Araştırma örneklemini oluşturan öğrencilerin \%79,2'sini kadın öğrenciler oluşturdu. Öğrencilerin $\% 11,54$ 'ünün düşük, $\% 45,38$ 'inin orta ve $\% 43,08$ 'inin yüksek fiziksel aktivite düzeyine sahip olduğu ortaya kondu. Vücut kitle indeksi ile fiziksel aktivite arasında anlamlı bir ilişki bulunamadı(p>0,05). Boy uzunluğu, vücut ağırlığı ve cinsiyet fiziksel aktivite düzeyini etkileyen faktörler olarak belirlendi. Erkek öğrencilerde fiziksel aktivite düzeyinin anlamlı

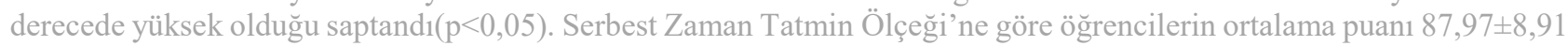
olarak elde edildi. Obez öğrencilerde serbest zaman memnuniyet oranı daha yüksek bulundu. Öğrencilerin Serbest Zaman Tatmin Ölçeği ve Uluslararası Fiziksel Aktivite Ölçeği toplam puanları arasında negatif yönde anlamlı bir ilişki saptandi $(\mathrm{r}=-0,180, \mathrm{p}<0,05)$.

Sonuç: Araştırmanın sonucuna göre meslek yüksekokulu öğrencilerinin fiziksel aktivite düzeyleri ve serbest zaman memnuniyetleri yeterince yüksek değildi. Dünya Sağlık Örgütü'nün tavsiyeleri doğrultusunda genç yetişkinlerde fiziksel aktiviteyi ve aktif serbest zaman aktivitelerini artırmaya yönelik adımların atılması, sağlıklı bir yaşam için önem arz etmektedir.

Anahtar sözcükler: Egzersiz, boş zaman aktiviteleri, öğrenciler, rekreasyon, sağlıklı yaşam tarzı, sporlar

\section{INTRODUCTION}

All the activities that consume energy and increase the heart and respiratory rates as a result of using the muscles and joints in our body are considered as physical activity ${ }^{1}$. Regular exercises or activities such as walking, dancing, cycling as hobbies are all examples of physical activities. However, activities such as watching television, sitting, and sleeping, where the energy level spent in the body is at rest are not considered as physical activities ${ }^{2}$. Today, both the increase in desk-bound activities and the time spent on computers or tablets cause a reduction in the level of physical activity and lead people to a sedentary lifestyle ${ }^{2,3}$. Physical inactivity is one of the factors that create health problems such as obesity and depression, which we frequently encounter in young people in recent years ${ }^{4}$. One of the underlying causes of chronic diseases such as cancer, diabetes, and stroke, the incidence of which increases with advancing age, is the decrease in the level of physical activity ${ }^{5}$. Therefore, adopting an active lifestyle at an early age and increasing the level of physical activity is an important target of health systems ${ }^{6}$.

Leisure time activities that resemble physical activities are the activities that individuals perform individually or in groups in their spare time according to their own wishes ${ }^{7}$. The concept of free time, which is also expressed as a leisure time activity or recreational activity in the literature, is a time interval that evokes a sense of fun, satisfaction, and happiness ${ }^{8,9}$. Unlike physical activities, in addition to dancing, swimming and doing sports activities, every activity that pleases individuals such as watching television, spending time on tablets, reading books, and making individuals happy is a kind of free time activity ${ }^{8}$. Therefore, to what extent people are satisfied with the activity they do in their spare time depends entirely on individual perception. Studies have reported that this time interval devoted to people has many benefits for physical and psychological development and socialization ${ }^{10}$.

Physical activity and leisure time activities, which seem to be close to each other, differ in many ways. Physical activity has to be associated with mobility, but leisure time activities don't have to be ${ }^{6,8}$. The difference between these two concepts should be emphasized sufficiently and their correct understanding should be ensured. Consciousness to be created in this direction in the society will help adopt a healthy lifestyle. For this reason, this study aimed to examine the relationship between physical activity and leisure time activities in higher vocational school students, which constitute a significant part of the young adult population, and to determine the factors affecting the physical activity and leisure time satisfaction.

\section{MATERIAL AND METHODS}

The ethics committee permission of the research was obtained from Karadeniz Technical University Medical Faculty Scientific Research Ethics Committee (approval number 24237859-859). The students were informed about the study, their verbal and written consents were obtained, and the data were collected following the "Helsinki Declaration" principles. 


\section{Design of the research}

The population of this cross-sectional and descriptive study consisted of 200 students studying in the Elderly Care, Physiotherapy, and First Aid and Emergency programs in a university. The sample of the study consisted of 130 students who agreed to participate in the study and filled the information form comletely. Students who are not actively attending school excluded from the investigation. All the data was obtained between December 2019 to January 2020. The forms used in the study consisted of two separate sections and were applied to the students at the same time. The first section included the socio-demographic data form, and the second section included two separate scales evaluating physical activity level and leisure time satisfaction.

\section{Scales}

In this study, the International Physical Activity questionnaire (IPAQ) short form was used to obtain objective data about students' level of health-related physical activity. This scale was tested on individuals between the ages of 15 and 69, and its Turkish validity and reliability were performed ${ }^{11,12}$. It consists of four separate sections and 7 questions and includes questions related to the physical activities that individuals have performed for at least 10 minutes for the last one week. The metabolic equivalent (MET), which corresponds to the basal metabolic rate, is used on a scale basis to determine the level of physical activity. The IPAQ calculates the total amount of MET spent by determining the number of days and how long individuals perform severe or moderate physical activity and walking per week. In line with the literature, the physical activity levels of the participants in our study were classified as "low, moderate and high" according to their total physical activity scores ${ }^{11}$.
Another scale employed in the study was the Leisure Time Satisfaction Scale (LTSS), which provides information about students' leisure time satisfaction levels. There are short and long versions of the scale, but the long version whose Turkish validity and reliability study was performed was preferred in our study, ${ }^{13,14}$. After factor analysis, the scale including 51 items in its original version was reduced to 39 items. The Cronbach's alpha coefficient of the overall scale rated as a five-Likert type was reported as .92. In the LTSS, as the total score increases, the leisure time satisfaction level of individuals increases ${ }^{14}$.

The socio-demographic data forms and the scales were administered to the students outside the class hours, and it took about 20 minutes to collect the data.

\section{Data analysis}

The statistical data of the study were evaluated using IBM SPSS 23.0 program. Percentage and frequency for categorical variables, mean, standard deviation, minimum and maximum values for continuous variables were used to produce descriptive statistics about the participants. Kruskal Wallis, Mann Whitney U, ANOVA, and correlation analyses were used in the analysis of the data. The results were evaluated at a 95\% confidence interval and a significance level of $\mathrm{p}<0.05$.

\section{RESULTS}

$79.23 \%$ of students were female and the average age of all students participating in our study was $20 \pm 1.57$. Average height, weight and body mass index of students are $166.36 \pm 8.65 \mathrm{~cm}$, $62.71 \pm 11.48 \mathrm{~kg}, \quad 22.56 \pm 3.82 \mathrm{~kg} / \mathrm{m}^{2} \quad$ respectively. Other descriptive features about participants seen in table 1. (Table 1). 
Table 1: Descriptive Characteristics of the Participants ( $\mathrm{n}=130)$

\begin{tabular}{|l|c|c|}
\hline Characteristics & n & \% \\
\hline Gender & 103 & 79.23 \\
Female & 27 & 20.77 \\
Male & & \\
\hline Program & 38 & 29.23 \\
First and Emergency Aid & 58 & 44.61 \\
Elderly care & 34 & 26.16 \\
Physiotherapy & & \\
\hline Class & 116 & 89.23 \\
1st year & 14 & 10.77 \\
2nd year & & \\
\hline Use of cigarette & 40 & 30.77 \\
Yes & 90 & 69.23 \\
No & & \\
\hline BMI Classification(kg/m $\left.{ }^{2}\right)$ & 18 & 13.85 \\
<18.5 Underweight & 87 & 66.92 \\
18.50-24.99 Normal weight & 20 & 15.38 \\
25-29.99 Overweight & 5 & 3.85 \\
$>30$ & & \\
\hline Obese & & \\
\hline
\end{tabular}

BMI: Body Mass Index

Table 2: Distribution of Students' International Physical Activity Questionnaire Levels and Total Scores $(\mathrm{n}=130)$

\begin{tabular}{|l|c|c|}
\hline \multicolumn{1}{|c|}{ Physical Activity Level } & n & \% \\
\hline Low Physical Activity $<600$ & 15 & 11.54 \\
Moderate Physical Activity 600-3000 & 59 & 45.38 \\
High Physical Activity >3000 & 56 & 43.08 \\
\hline Total Score & Min-Max & $\mathrm{X} \pm \mathrm{SD}$ \\
& $231.00-13650.00$ & $3548.75 \pm 2984.86$ \\
\hline
\end{tabular}

Min:Minimum, Max: Maksimum

Table 2 shows the distribution of the students' physical activity levels, and their total score averages according to IPAQ. According to the table, $45.38 \%$ of students had a moderate level of physical activity, and $43.08 \%$ had a high level of physical activity (Table 2).

Table 3 shows the comparison of students' IPAQ Average scores and their descriptive characteristics. The correlation analysis showed that there was no statistically significant relationship between age $(\mathrm{r}=0.011, \mathrm{p}=0.897)$ and the IPAQ average scores. Also there was no statistically significant relationship between average body mass index value (BMI) and the IPAQ average scores $(\mathrm{r}=0.023, \mathrm{p}=0.793)$ (Table 3$)$. The correlation analysis also determined that the difference between the students' average height $(\mathrm{r}=0.276, \mathrm{p}=0.01)$, body weight $(\mathrm{r}=0.202, \mathrm{p}=0.021)$ and the IPAQ scores was statistically significant, and there was a positive, moderately strong relationship between them (Table 3 ). This situation shows that as the average height and weight of the students increase, the IPAQ average score increases. The scores of the IPAQ of male students included in the study $(5145.74 \pm 3389.55)$ were higher than those of female students, and the difference between the groups was statistically significant (Table 3). The IPAQ score averages of the second-year students (4277.21 \pm 4036.20$)$, students studying in the physiotherapy program

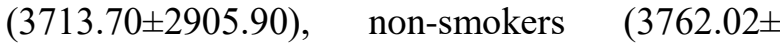
3197.28) and normal-weight students (3941.19 \pm 3226.88$)$ were higher, but the difference 
between the groups was not statistically significant (Table 3).

The average of Leisure Time Satisfaction Scale total score was calculated as $87.97 \pm 8.91$. Also minimum and maximum scores are calculated as 13 and 177 respectively. Table 4 shows the comparison of students' LTSS average scores and their descriptive characteristics. According to the correlation analysis, no statistically significant relationship was found between the average age $(\mathrm{p}=0.586)$, weight $(\mathrm{p}=0.970)$ and BMI scores $(\mathrm{p}=0.377)$ of the students and their LTSS scores
(Table 4). The correlation analysis showed that the difference between the students' average height and the LTSS score $(r=0.224, p=0.010)$ was statistically significant, and there was a moderately strong negative correlation between them. Accordingly, as the average height increased, the average score of the LTSS decreased (Table 4). Although the average LTSS scores of female (89.86 \pm 28.98$)$, second year ( $94.50 \pm 37.95)$, Elderly Care program $(92.82 \pm 59.65)$ and smoking students (88.12 \pm 28.87$)$ were high, but the difference between the groups was not statistically significant (Table 4).

Table 3: The Comparison of Students' International Physical Activity Questionnaire Averages and Their Descriptive Characteristics

\begin{tabular}{|c|c|c|}
\hline Variables & $\mathbf{X} \pm \mathbf{S D}$ & Tests \\
\hline Age & & $\begin{array}{l}\mathrm{r}=0.011 \\
\mathrm{p}=0.897 *\end{array}$ \\
\hline Height & & $\begin{array}{l}\mathrm{r}=0.276 \\
\mathrm{p}=0.01 * *\end{array}$ \\
\hline Weight & & $\begin{array}{l}\mathrm{r}=0.202 \\
\mathrm{p}=0.021 * * *\end{array}$ \\
\hline BMI & & $\begin{array}{l}\mathrm{r}=0.023 \\
\mathrm{p}=0.793^{*}\end{array}$ \\
\hline $\begin{array}{l}\text { Gender***** } \\
\text { Female } \\
\text { Male }\end{array}$ & $\begin{array}{l}3125.64 \pm 2741.06 \\
5145.74 \pm 3389.55\end{array}$ & $\begin{array}{l}Z=-3.160 \\
p=0.02\end{array}$ \\
\hline \multicolumn{3}{|l|}{ Class $* * * *$} \\
\hline 1 st year & $3456.85 \pm 2847.10$ & $Z=-0.511$ \\
\hline 2nd year & $4277.21 \pm 4036.20$ & $\mathrm{p}=0.609$ \\
\hline $\begin{array}{l}\text { Program ***** } \\
\text { First and Emergency Aid } \\
\text { Elderly Care } \\
\text { Physiotherapy }\end{array}$ & $\begin{array}{l}3665.28 \pm 2623.90 \\
3367.74 \pm 3286.44 \\
3713.70 \pm 2905.90\end{array}$ & $\begin{array}{l}\mathrm{KW}=1.733 \\
\mathrm{p}=0.420\end{array}$ \\
\hline \multicolumn{3}{|l|}{ Use of Cigarette $* * * *$} \\
\hline $\begin{array}{l}\text { Yes } \\
\text { No }\end{array}$ & \begin{tabular}{|l|}
$3057.35 \pm 2422.20$ \\
$3762.02 \pm 3197.28$ \\
\end{tabular} & $\begin{array}{l}Z=-0.921 \\
p=0.357\end{array}$ \\
\hline $\begin{array}{l}\text { BMI Classification } * * * * * * \\
<18.5 \quad \text { Underweight }\end{array}$ & $2103.55 \pm 1549.13$ & \\
\hline 18.51-24.99 Normal & $3941.19 \pm 3226.88$ & $\mathrm{KW}=2.165$ \\
\hline 25-29.99 Overweight & $3137.00 \pm 2345.90$ & $\mathrm{p}=0.539$ \\
\hline$>30 \quad$ Obese & $3437.60 \pm 3778.75$ & \\
\hline
\end{tabular}

*Spearman Correlation test $* *$ Pearson Correlation test $\mathrm{p}<0.01 * * *$ Pearson Correlation test

**** Mann-whitney $\mathrm{U}$ t test $* * * * *$ Kruskal Wallis test 
Table 4: The Comparison of Students' Leisure Time Satisfaction Scale Average Scores and Their Descriptive Characteristics $(\mathrm{n}=130)$

\begin{tabular}{|c|c|c|}
\hline Variables & $\mathrm{X} \pm \mathrm{SD}$ & Tests \\
\hline Age & & $\begin{array}{l}r=-0.048 \\
P=0.586^{*}\end{array}$ \\
\hline Height & & $\begin{array}{l}\mathrm{r}=-0.224 \\
\mathrm{P}=0.010^{*}\end{array}$ \\
\hline Weight & & $\begin{array}{l}\mathrm{r}=-0.003 \\
\mathrm{P}=0.970 * *\end{array}$ \\
\hline BMI & & $\begin{array}{l}\mathrm{r}=0.078 \\
\mathrm{P}=0.377 *\end{array}$ \\
\hline $\begin{array}{l}\text { Gender*** } \\
\text { Female } \\
\text { Male }\end{array}$ & $\begin{array}{l}89.86 \pm 28.98 \\
80.77 \pm 27.99\end{array}$ & $\begin{array}{l}Z=-1.702 \\
P=0.089\end{array}$ \\
\hline $\begin{array}{l}\text { Class } * * * \\
1 \text { st year } \\
2 \text { nd year }\end{array}$ & $\begin{array}{l}87.18 \pm 27.73 \\
94.50 \pm 37.95\end{array}$ & $\begin{array}{l}Z=-0.477 \\
P=0.633\end{array}$ \\
\hline $\begin{array}{l}\text { Program } * * * * \\
\text { First and Emergency Aid } \\
\text { Elderly Care } \\
\text { Physiotherapy }\end{array}$ & $\begin{array}{l}82.13 \pm 29.08 \\
92.82 \pm 59.65 \\
86.23 \pm 26.77\end{array}$ & $\begin{array}{l}\mathrm{KW}=2.519 \\
\mathrm{P}=0.284\end{array}$ \\
\hline $\begin{array}{l}\text { Use of Cigarette } * * * \\
\text { Yes } \\
\text { No }\end{array}$ & $\begin{array}{l}88.12 \pm 28.87 \\
87.91 \pm 29.09\end{array}$ & $\begin{array}{l}Z=-0.232 \\
P=0.816\end{array}$ \\
\hline $\begin{array}{ll}\text { BMI Classification } * * * * * * & \text { Underweight } \\
<18.5 & \text { Und } \\
18.51-24.99 & \text { Normal } \\
25-29.99 & \text { Overweight } \\
>30 & \text { Obese }\end{array}$ & $\begin{array}{r}100.44 \pm 39.67 \\
82.87 \pm 25.45 \\
90.95 \pm 23.06 \\
120.00 \pm 34.89\end{array}$ & $\begin{array}{l}\text { ANOVA }=4.467 \\
P=0.005\end{array}$ \\
\hline
\end{tabular}

BMI: Body Mass Index

In our study, the average LTSS scores (120.00 \pm 34.89$)$ of obese students were higher than non-obese students, and the difference between the groups was statistically significant (Table 4).

Also there was a negative correlation between students' LTSS and IPAQ total scores ( $\mathrm{r}=-0.180$, $\mathrm{p}=0.041$ ), and as the total score of the LTSS increased, the total score of the IPAQ decreased.

\section{DISCUSSION}

The American Medical Society for Sports Medicine informs that adults should do moderateintensity exercise for at least 30 minutes every day or most days of the week. In this way, the physical and mental well-being of individuals will be supported, and the quality of life will increase ${ }^{15}$. In our study planned in this direction, firstly, the degree of physical activity and the factors related to the physical activity level of the associate students were examined. According to the results, $11.5 \%$ of the participants had low, and $45.4 \%$ had moderate physical activity levels, but only $43.1 \%$ of them were physically active enough. In a study conducted on students studying in medicine and nursing departments in England, it was found that $19 \%$ of nursing students had low, $45 \%$ had moderate, and $36 \%$ had high physical activity levels. In the same study, it was revealed that $11 \%$, $41 \%$, and $48 \%$ of the medical students had low, moderate, and high level of physical activity, respectively ${ }^{16}$. In another study conducted with 
university students in Colombia, only $16.8 \%$ of students were found to be physically active ${ }^{17}$. Savci et al. conducted a study with 1097 university students studying in health-related undergraduate departments in our country and stated that approximately $15 \%$ of the students were physically inactive, $68 \%$ were moderately active, and the proportion of physically active students was only $18 \%{ }^{18}$. Although the studies report different results, the common conclusion is that the level of physical activity in the young population is not at a level to benefit the body in terms of health. This is a potential problem that will increase the prevalence of chronic diseases, patient burden, and health expenses that will occur in the following years. The 2018-2030 action plan issued by the World Health Organization(WHO) to prevent such problems highlights the importance of country policies that will ensure that all people are regularly active. Therefore, the concept of physical activity is becoming more and more important day by day 19 .

Another result of our research was that height, body weight, and gender were factors that affected the level of physical activity. Accordingly, the physical activity level of male students was significantly higher than female students. This result was consistent with the literature 18,20,21. Although the increase in weight and height was positively correlated with the level of physical activity, no significant relationship was found between body mass index and physical activity. With this aspect, our research is similar to a study conducted on university students in 2007. In that study positive correlation was found between height $(\mathrm{p}<0.03)$, body weight $(\mathrm{p}<0.011)$ and physical activity level ${ }^{22}$. Although the increase in physical activity level surprisingly increases with increasing body weight, it was thought that a low number of obese students $(n=5)$ may affect these results.

The leisure time satisfaction total average score obtained from the LTSS was 87.97. Considering that the maximum score of the scale is 195 , it was concluded that the students' leisure time satisfaction was not high enough. In another study conducted with university students in Turkey, the LTSS score was found as $136 .{ }^{23}$ Literature reports that high leisure time satisfaction of young people is an effective factor in the formation of a strong and solid characters and the development of psychosocial skills in society ${ }^{24}$. Moreover, increasing leisure time satisfaction contributes to the academic success and life satisfaction of students and family life in the coming years ${ }^{25}$. In our study, the low average value was linked with the students living far away from the city center and more rural areas, and thus having difficulty in accessing social opportunities.

Our study also displayed that there was a negative correlation between leisure time satisfaction scores and height, but no difference was observed between gender and leisure time satisfaction. Similarly, in a study administered in our country in 2018, no difference was found between female and male university students in terms of leisure time satisfaction ${ }^{25}$. Considering the World Health Organization body mass index classification in our study, it was a remarkable result that leisure time satisfaction was significantly higher in obese individuals, but a similar relationship could not be found with the level of physical activity. A study on university students informed that $44.4 \%$ of students read books or newspapers in their spare time, $11.5 \%$ had a rest and $10.3 \%$ watched television. However, the proportion of students who did sports listened to music and strolled around with their friends in their spare time was lower ${ }^{26}$. Terzioğlu et al. also determined that the number of university students who did physical activities in their spare time was quite low ${ }^{27}$. While a negative correlation existed between physical activity level and leisure time satisfaction in our study, a positive correlation was found between obesity and leisure time satisfaction. When these results are examined carefully, it can be thought that the students tend to passive leisure activities more as stated in the literature. A related study suggest that social media is the most widely used tool by students in their spare time ${ }^{28}$. It can be thought that university students preferred passive activities more in their free time and interpreted leisure time satisfaction mostly through passive activities. Accordingly, it can be said that passive leisure activities do not increase leisure time satisfaction in young people. Possible increases in the level of physical activity will also help turn leisure activities into hobbies requiring more active participation. According to the literature, increasing physical activity leads to an increase in neurotransmitters such as endorphins and serotonin in the body ${ }^{29}$. Therefore, it can be said that with the active leisure time, both physical activity level and leisure time satisfaction will increase. This should be confirmed by future studies.

The most important limitations in our study were that the whole population could not be reached and what type of free time activities participants considered when responding to LTSS was unknown. 


\section{CONCLUSION}

As a result, students of vocational schools should be encouraged for more physical activity. It should be questioned with which activities the students spend their free time. They should be informed about the benefits and harms of active and passive activities. The physical, psychological and social benefits of physical activity and the psycho-social benefits of leisure time should be combined.

\section{REFERENCES}

1. McArdle WD, Katch FI, Katch VL. Exercise physiology: energy, nutrition, and human performance. 8th ed. Philadelphia: Lippincott Williams \& Wilkins; 2014.

2. Pate RR, O'neill JR, Lobelo F. The evolving definition of "sedentary". Exercise and sport sciences reviews. 2008;36(4):173-178.

3. Kilinç H, Bayrakdar A, Celik B, Mollaogullari $\mathrm{H}$, Gencer YG. Physical activity level and quality of life of university students Journal of Human Science, 2016;13(3): 3794-806.

4. Bailey AP, Hetrick SE, Rosenbaum S, Purcell R, Parker AG. Treating depression with physical activity in adolescents and young adults: a systematic review and meta-analysis of randomised controlled trials. Psychol Med, 2017;8;(07):1068-83.

5. Peluso MA, Guerra de Andrade LH. Physical activity and mental health: the association between exercise and mood. Clinics. 2005;60(1):61-70.

6. Pate RR, Pratt M, Blair SN, Haskell WL, Macera CA, Bouchard C, et al. Physical activity and public health. A recommendation from the Centers for Disease Control and Prevention and the American College of Sports Medicine. JAMA 1995;273:402-07.

7. Collins JR, Valerius L, King TC, Graham AP. The relationship between college students' selfesteem and the frequency and importance of their participation in recreational activities. Recreational Sports Journal. 2001;25(2):38-47.

8. Onder S. A research on determination of recreational tendency and demands of students of Selcuk university. Selcuk J Agric Food Sci. 2003;17(32):31-38.

9. Chiu LK, Kayat K. Psychological Determinants of Leisure Time Physical Activity Participation among Public University
Students in Malaysia. Asian Journal of Teaching \& Learning in Higher Education. 2010;2(2): 33-45.

10. Kiper T. Determination of Recreational Tendencies and Demands of Students at Namık Kemal University, Faculty Agriculture (Tekirdağ). Journal of Tekirdag Agricultural Faculty. 2009;6(2):191-201.

11. Öztürk M. A research on reliability and validity of international physical activity questionnaire and determination of physical activity level in university students. Hacettepe University Ankara, Master Thesis. 2005.

12. Yeşil P, Altıok M, Erdoğan S. Physical activity levels in percutaneus intracoronary intervention patients and the factors influcing these levels. Mersin University Journal of Health Sciences. 2013;6(1): 20-14.

13. Gokce H. Examining of the leisure satisfaction with the relation between life satisfaction and socio - demographic variables. Pamukkale University Institute of health sciences, Master Thesis. 2008.

14. Karlı U, Polat E, Yilmaz B, Kocak S. Reliability and validity study of Leisure Satisfaction Scale (LSS-long version). Hacettepe Journal of Sport Sciences 2008;19(2):80-91.

15. Driskell JA, Kim YN, Goebel KJ. Few differences found in the typical eating and physical activity habits of lower-level and upper-level university students. J Am Diet Assoc. 2005;105:798-801.

16. Blake H, Stanulewicz N, Mcgill F. Predictors of physical activity and barriers to exercise in nursing and medical students. J Adv Nurs. 2016;73(4):917-29.

17. Garcia FP, Herazo YB, Tuesca RM. Levels of physical activity among colombian university students. Revista médica de Chile. 2015;143(11):1411-18.

18. Savci S, Ozturk M, Arikan H, Inal Ince D, Tokgozoglu L. Physical activity levels of university students. Arch Turk Soc Cardiol 2006;34(3):166-72.

19. World Health Organiztion (WHO). Global action plan on physical activity 2018-2030: more active people for a healthier world. Geneva: World Health Organization; 2018.

20. Vašíčková J, Groffik D, Frömel K, Chmelík F, Wasowicz W. Determining gender differences in adolescent physical activity levels using 
IPAQ long form and pedometers. Ann agr env med. 2012;20(4): 749-55.

21. Grasdalsmoen M, Eriksen HR, Lønning KJ, Sivertsen B. Physical exercise and body-mass index in young adults: a national survey of Norwegian university students. BMC Public Health. 2019;19:1354.

22. Baş Aslan U, Livanelioglu A, Aslan S. Evaluation of physical activity level in undergraduate students by two methods. Turk J Physiother Rehabil. 2007;18(1):19.

23. Kocaman Karoğlu A, Atasoy B. The Relationship between Social Media Usage and Leisure Time Satisfaction. Mersin Üniversitesi Eğitim Fakültesi Dergisi, 2018; 42(2): 826-39.

24. Huang CY, Carleton B. The relationships among leisure participation, leisure satisfaction and life satisfaction of college students in Taiwan. J Exerc Scind Fit. 2003;1(2):129-132.

25. Yagmur R. Comparison of leisure time aktivities between school of physical education and other colleges in students of Afyon Kocatepe University Afyon Kocatepe University Institute of Health Sciences, Master Thesis. 2006.

26. Kır İ. Leisure Activities Of Higher Education Youth: KSÜ Example. Firat University Journal of Social Science. 2007;17(2):307-28.

27. Terzioğlu A, Yazıcı, M. Graduate Student's Perception And Use Of Leisure Time (Atatürk University Example).Erzincan University Journal of Education Faculty. 2003;5(2):1-31.

28. Kocaman-karoğlu A, Atasoy B. The Relationship between Social Media Usage and Leisure Time Satisfaction. Mersin University Journal of Education Faculty. 2018;14(2):826-39.

29. Dishman RK, Oconnor PJ. Lessons in exercise neurobiology: The case of endorphins. Ment. Health Phys. Act. 2009;2(1):4-9. 